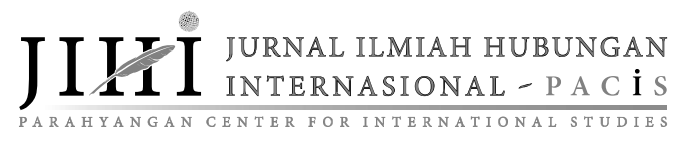

JURNAL ILMIAH HUBUNGAN INTERNASIONAL

Parahyangan Centre for International Studies (PACIS)

Parahyangan Catholic University

Bandung

ISSN: 1693-556x

E-ISSN: 2406-8748

VOLUME 17 No. 2

Hal. 200 - 218

https://doi.org/10.26593/jihi.v17i2.4111.200-218

oktad72@gmail.com 


\title{
Implementasi Gender Mainstreaming dalam Konteks Pembangunan: Studi Kasus Keberhasilan Kesetaraan Gender di Filipina tahun 2018
}

\author{
Okta Meryana Dewi ${ }^{1}$ \\ ${ }^{1}$ Departemen Hubungan Internasional, Universitas Gadjah Mada, oktad72@gmail.com
}

\begin{abstract}
ABSTRAK
Filipina yang dikenal sebagai negara patriarki diera kolonialisme kini menjadi satu-satunya negara yang yang memiliki tingkat kesetaraan gender tertinggi di Asia. Pengembangan kebijakan pemerintah yang berfokus pada peningkatan kesetaraan gender, menjadikan laki-laki dan perempuan memiliki akses yang sama terhadap semua sumber daya. Hal ini menimbulkan pertanyaan tentang implementasi gender mainstreaming yang dilihat dari konteks pembangunan di Filipina dalam menegakkan kebijakan kesetaraan gender. Tulisan ini mengelaborasikan bahwa implementasi konsep gender mainstreaming yang mengintegrasikan perspektif gender ke dalam persiapan, perancangan, penerapan, monitoring dan evaluasi kebijakan, peraturan pelaksanaan dan program pembiayaan, sebagai salah satu kunci keberasilan kesetaraan gender di Filipina. Dalam artikel ini, penulis menjabarkan tiga argumen utama keberhasilan kesetaraan gender di Filipina pada tulisan ini: pertama, diaodpsinya terminologi gender mainstreaming. Kedua, penerapan gender mainstreaming yang dibuktikan dengan dibentuknya beberapa undangundang peraturan serta program terkait penerapan kesetaraan gender yaitu The Magna Carta of Women (MCW), The Philippine Development Plan for Women (PDPW) 1989-1992, dan The Philippine Plan for Gender-Responsive Development (PPGD) 1995-2025. Ketiga, implementasi gender mainstreaming dibeberapa sektor diantaranya partisipasi ekonomi dan peluang, pencapaian pendidikan, kesehatan dan kelangsungan hidup, dan pemberdayaan politik. Keseriusan dan kesadaran tinggi pemerintah mengenai pentingya kesetaraan gender konteks pembangunan dituangkan dalam peraturan serta Undang-Undang sebagai kunci keberhasilan Filipina dalam penerapan kesetaraan gender.
\end{abstract}

Kata Kunci: Kesetaraan gender, perempuan \& pembangunan, gender mainstreaming, Filipina

\begin{abstract}
The Philippines, which is known as a patriarchal country in the era of colonialism, is now the only country that has the highest level of gender equality in Asia. Development of government policies that focus on improving gender equality, giving men and women equal access to all resources. This raises questions about the implementation of gender mainstreaming seen from the context of development in the Philippines in enforcing gender equality policies. This paper elaborates that the implementation of the concept of gender mainstreaming which integrates a gender perspective into the preparation, design, implementation, monitoring and evaluation of policies, implementing regulations and financing programs, is one of the keys to the success of gender equality in the Philippines. In this article, the author outlines three main arguments for the success of gender equality in the Philippines in this paper: first, the diodection of the terminology of gender mainstreaming. Second, the implementation of gender mainstaking as evidenced by the formation of several laws and programs related to the implementation of gender equality, namely The Magna Carta of Women (MCW), The Philippine Development Plan for Women (PDPW) 1989-1992, and The Philippine Plan for Gender-Responsive Development (PPGD) 1995-2025. Third, the implementation of gender mainstreaming in several sectors including economic participation and opportunities, educational attainment, health and survival, and political empowerment. The seriousness and high awareness of the government regarding the importance of gender equality in the development context is outlined in
\end{abstract}


201 Okta Meryana Dewi | Implementasi Gender Mainstreaming dalam Konteks Pembangunan: Studi Kasus Keberhasilan

Kesetaraan Gender di Filipina tahun 2018

regulations and laws as keys which are then implemented in all policies. In the elaboration, this paper will use qualitative research methods sourced from secondary data.

Keywords: Gender Equality, women \& Development, Gender mainstreaming, Philippines

\section{Pendahuluan}

Dalam beberapa dekade belakang, analis pembangunan mengintegrasikan kaitan antara gender dan pembangunan. Sebelum adanya istilah gender yang diperkenalkan pada tahun 1976, perempuan dan laki-laki selalu diidentifikasi berdasarkan jenis kelamin yang diferensiasi secara biologis. Padahal sejatinya makna gender sebagai pembedaan antara maskulinitas dan feminitas yang dibangun melalui konstruksi sosial yang membentuk identitas. Identitas inilah yang mengarah pada pembagian peran sosial, tanggung jawab dan kewajiban, hak, sikap, dan posisi perempuan dan laki-laki dalam masyarakat, baik dalam konteks politik dan ekonomi atau bahkan pada aspek kehidupan lainnya. ${ }^{1}$ Pada realitanya dalam konteks pembangunan seringkali dalam implementasinya bias gender. Hal ini diartikan meskipun adanya kemajuan besar gender dalam dunia internasional, namun kebijakan pembangunan tetap menjadi suatu permasalahan. Penyebab utamanya karena adanya ketidakadilan dalam menjalankan agenda pembangunan bagi perempuan. ${ }^{2}$ Menghindari ketidaksetaraan ini, maka diperlukan adanya implementasi dari konsep Gender and Development $(G A D)$. GAD memastikan adanya kesetaraan dalam kontrol, pemanfaatan serta partisipasi yang sama antara perempuan dan laki-laki dalam konteks pembangunan. ${ }^{3}$

\footnotetext{
${ }^{1}$ L. Sjoberg, Gender and International Security Feminist perspectives, Routledge, New York, 2010, p.11

${ }^{2}$ World Bank, Gender Equality and Development: World Development Report 2012, The International Bank for Reconstruction and Development, Washington DC, 2011. ${ }^{3}$ J. L. Parpart (eds), Theoretical Perspectives on Gender and Development, International Development Research Centre, Canada, 2000, p.39.
}

Dalam studi feminisme, GAD dikategorikan dalam "gender mainstreaiming" atau pengarusutamaan gender.

Gender mainstreaming mengintegrasikan perspektif gender ke dalam persiapan, perancangan, penerapan, monitoring dan evaluasi kebijakan, peraturan pelaksanaan dan program pembiayaan, dengan tujuan mendukung kesetaraan antara laki-laki dan perempuan. ${ }^{4}$ Setengah dari populasi negara adalah perempuan, namun mereka hanya memegang sekitar seperlima dari posisi yang dipilih pemerintah. Realita ini menggambarkan bahwa partisipasi perempuan di semua bidang kehidupan sangat penting dalam mewujudkan peran mereka sebagai agen dan penerima manfaat pembangunan sepenuhnya.

Menanggapi realita yang ada bahwa tidak semua negara-negara di dunia mengindahkan ataupun menggunakan konsep GAD dalam program pembangunan. Banyak spekulasi beranggapan bahwa negara memang dengan sengaja tidak memberikan ruang kepada perempuan dalam konteks pembangunan. Kalaupun peluang itu ada, namun perempuan hanya menduduki posisi dan peran tertentu dan menempatkan laki-laki dengan posisi lebih tinggi.

Kondisi ini berbanding terbalik dengan Filipina, berbicara mengenai kesetaraan gender menurut global gender gap 2018 salah satu negara di Asia Tenggara ini menduduki

\footnotetext{
${ }^{4}$ C. Kabonesa, 'Gender Mainstreaming and Implications for Peace', dalam D.Rodríguez \& E.N.Togboa (ED), Gender and Peace Building in Africa, University for Peace, Costa Rica, 2005, p.17.
} 
peringkat ke-8 di dunia dan peringkat tertinggi se-Asia sebagai negara dengan tingkat kesetaraan gender. ${ }^{5}$ Pendudukan posisi ini bukan tanpa alasan, keberhasilan Filipina dalam menciptakan kesetaraan posisi antara perempuan dan laki-laki karena kesadaran besar para pemerintah dalam menciptakan peraturan GAD yang dituangkan dalam Undang-Undang. Terutama difokuskan dalam tiga hal yaitu The Magna Carta of Women (MCW) dan The Philippine Plan for Gender-Responsive Development (PPGD) 1995-2025. Aturanaturan ini yang kemudian diimplementasi di berbagai sektor yaitu ekonomi, pendidikan, kesehatan dan politik sekaligus sebagai bahan dan indikator utama keberhasilan kesetaraan gender di Filipina.

Keberhasilan Filipina kemudian menjadi cerminan bagi negara-negara ASEAN dalam menangani isu-isu prioritas perempuan dan gender di ASEAN. Hal tersebut dibuktikan dengan diselenggarakannya Konferensi Pejabat Senior, yang dipimpin oleh ASEAN Committee on Women (ACW), melalui focal point Filipina yaitu Philippine Commission on Women (PCW). Konferensi ini bertujuan memperdalam pemahaman mereka tentang Gender and development (GAD) terutama dalam menangani isu-isu perempuan yang diakui secara internasional yang relevan dengan mandat badan-badan sektoral ASEAN Socio-Cultural Community (ASCC). Di antaranya praktik yang baik, Gender Mainstreaming, and elimination of Violence Against Women (VAW) and Violence Against Children (VAC). ${ }^{6}$

Meskipun kemudian, penulis mendapati bahwa tidak semua dari keempat sektor

\footnotetext{
${ }^{5}$ World Economic Forum, Global Gender Gap Report 2018, Committed to improving the state of the world, Switzerland, 2020, p.7.

${ }^{6}$ The Philippine news agency, PH hosts ASEAN confab to advance gender mainstreaming, diakses melalui<https://www.pna.gov.ph/articles/1039537>, di akses pada 15 sept 2021.
}

(ekonomi, pendidikan, kesehatan dan politik) tersebut berjalan baik, terutama pada sektor kesehatan yang masih perlu mendapat perhatian besar para pemerintah Filipina. Di sisi lain, Filipina menduduki peringkat terbaik dalam sektor politik. Para perempuan Filipina dianggap sebagai pemecah rekor di Asia Tenggara dengan partisipasi perempuan terbanyak yang menduduki roda pemerintahan.

Pemerintah dan para stakeholder Filipina memasukkan kesetaraan gender dalam kebijakan dan program menuju pencapaian pembangunan berkelanjutan (UNDP Philippines , 2010). Pernyataan ini mengartikan bahwa Filipina dapat menjadi negara yang mempunyai kesetaraan gender tertinggi di Asia, karena pemerintah Filipina sadar akan pentingnya gender dalam pembangunan negara. Seperti adanya sebuah kerangka kerja dari program United Nations Development Programme (UNDP) yang diimplementasikan pemerintah Filipina dalam undang-undang. Dimana kerangka kerja ini bertujuan untuk memantau serta mengevaluasi program kesetaraan pemberdayaan perempuan.

Penulis memahami bahwa keberhasilan pembangunan tidak hanya dilihat dari efek ekonomi, namun dilihat bagaimana perempuan dan laki-laki dapat bekerja secara bersama. Untuk itu, dalam penulisan ini penulis akan memusatkan fokus pada 3 faktor sebagai argumen utama dari keberhasilan Filipina dalam penerapan GAD, diantaranya yaitu pertama, adanya The Magna Carta of Women (MCW). Kedua, The Philippine Plan for GenderResponsive Development (PPGD) 1995-2025. dan Ketiga, Implementasi penerapan GAD diberbagai sektor yaitu ekonomi, politik pendidikan dan kesehatan. 
203 Okta Meryana Dewi | Implementasi Gender Mainstreaming dalam Konteks Pembangunan: Studi Kasus Keberhasilan Kesetaraan Gender di Filipina tahun 2018

\section{Kerangka Konseptual}

\section{Gender mainstreaming}

Gender mainstreaming diperkenalkan dalam The Beijing Declaration and Platform for Action tahun 1995, sebagai keluaran Konferensi Dunia Keempat tentang Perempuan yang menegaskan bahwa "Pemerintah dan aktor lain harus mempromosikan kebijakan yang aktif dan terlihat dari pengarusutamaan perspektif gender ke dalam semua kebijakan dan program, sehingga sebelum keputusan diambil, analisis dibuat tentang dampaknya terhadap perempuan dan laki-laki". Konsep ini dikembangkan karena adanya keprihatinan feminis dalam konteks pembangunan yang telah lama dieksplorasi, sehingga memasukkan kesetaraan gender dalam proses dan tujuan pembangunan.

Pemerintah dan aktor lainnya termasuk organisasi internasional didesak untuk mengadopsi konsep gender mainstreaming sebagai bagian dari tujuan strategis dan tindakan di dua belas bidang perhatian kritis (Women and poverty, Education and training of women, Violence against women, Women and armed conflict, Women and the economy, Women in power and decision-making, Institutional mechanisms, Human rights of women, Education and Training of Women, Women and the media, Women and the environment, The girl child) ${ }^{7}$

Dalam persepektif feminisme, menurut Kabonesa bahwa gender mainstreaming sebagai suatu strategi untuk mewujudkan kesetaraan gender dengan mengintegrasikan perspektif gender ke dalam persiapan, perancangan, penerapan, monitoring dan evaluasi kebijakan, peraturan pelaksanaan dan program pembiayaan, dengan tujuan mendukung kesetaraan antara laki-laki dan perempuan, dan menghapus

\footnotetext{
${ }^{7}$ United Women, "Beijing Declaration and Platform Action : Beijing +5 Political Declaration and Outcome", Fourth World Conference on Women, New York, 4-15 September 1995.
}

diskriminasi. ${ }^{8}$ Caroline Moser and Annalisa Moser, praktik pengarusutamaan gender dapat dilihat dalam tiga tahap: mengadopsi terminologi kesetaraan gender dan gender mainstreaming, menerapkan kebijakan gender mainstreaming, dan mengimplementasikan gender mainstreaming:

\section{Mengadopsi terminologi Gender mainstreaming}

Dewan Ekonomi dan Sosial PBB atau The UN Economic and Social Council (UN ECOSOC) pada tahun 1997 mendefinisikan gender mainstreaming sebagai mencapai kebijakan kesetaraan gender, yaitu proses menilai implikasi bagi perempuan dan laki-laki dari setiap tindakan yang direncanakan, termasuk Undang-Undang, kebijakan atau program, di semua bidang dan di semua tingkatan. Strategi untuk menjadikan keprihatinan dan pengalaman perempuan serta laki-laki sebagai dimensi integral dari desain, implementasi, pemantauan dan evaluasi kebijakan dan program di semua bidang politik, ekonomi dan sosial sehingga perempuan dan laki-laki mendapat manfaat yang sama dan ketidaksetaraan tidak dilestarikan. ${ }^{9}$ Salah satu upaya untuk mengadopsi pengarusutamaan gender adalah melalui pembentukan unit atau divisi khusus di lembaga yang menangani masalah perempuan dan gender. ${ }^{10}$

Gender mainstreaming tidak bisa lepas sebagai pelembagaan isu gender dalam konteks pembangunan. Pembuktiannya ialah sejak Konferensi Perempuan Dunia Keempat PBB di

\footnotetext{
${ }^{8}$ C. Kabonesa, 'Gender Mainstreaming and Implications for Peace', dalam D.Rodríguez \& E.N.Togboa (ED), Gender and Peace Building in Africa, University for Peace, Costa Rica, 2005, p.17.

${ }^{9}$ United Nations, 'Gender mainstreaming an Overview', Office of the Special Adviser on Gender Issues and Advancement of Women, New York, 2002. ${ }^{10}$ Athiqah Nur Alami, 'The Implementation of Gender Mainstreaming in ASEAN', The Indonesian Journal of Southeast Asian Studies, Vol. 1, No. 2, January 2018, pp. 185-207, diakses pada 07 Agustus 2020.
} 
204 Okta Meryana Dewi | Implementasi Gender Mainstreaming dalam Konteks Pembangunan: Studi Kasus Keberhasilan Kesetaraan Gender di Filipina tahun 2018

Beijing tahun 1995, pengarusutamaan telah disahkan dan diadopsi serta diimplementasikan oleh berbagai organisasi internasional, seperti world bank, United Nations Development Programme (UNDP), Organization for Security and Co-operation in Europe (OSCE), European Union (EU). Seperti adanya pembentukan Women in Development (WID) pada tahun 1980, yang digantikan oleh pendekatan Gender and Development (GAD) pada tahun 1990-an. ${ }^{11}$

Sejak konferensi PBB, gender mainstreaming telah diadopsi oleh Uni Eropa sebagai dasar kebijakan gendernya, bahkan Uni Eropa dianggap sebagai aktor utama dalam pengembangan pengarusutamaan gender di periode kontemporer. Uni Eropa telah menggunakan berbagai instrumen untuk mengejar agenda kesetaraan gendernya. Contohnya adanya pembentukan European Commission's third medium-term Community action programme on equal opportunities for women and men (1991-1995). Dewan Menteri Nordik telah memutuskan Program Kerja Sama Nordik pada Kesetaraan Gender 1995-2000, diadopsi pada Maret 1995 mengambil langkah aktif untuk memiliki aspek kesetaraan gender dimasukkan dalam semua bidang kebijakan dan di semua tingkatan. Pernyataan tersebut merupakan pilar utama strategi kerja sama dalam kesetaraan gender. Selanjutnya diputuskan untuk mengambil langkah aktif menguji model integrasi perspektif gender. Proyek percontohan tiga tahun itu diluncurkan pada tahun 1997, dengan tujuan mengembangkan dan menguji metode dan alat untuk gender mainstreaming. ${ }^{12}$

\footnotetext{
${ }^{11}$ Björg Ryan, Gender Mainstreaming and Empowerment Concepts studied in a development cooperation programme in Kenya supported by Sweden, Master Thesis in Africa and International Development

Centre for Africa Studies, August, 2007.

${ }^{12}$ UNHCR, 'Gender mainstreaming: Conceptual framework, methodology and presentation of good practices', Final Report of Activities of the Group of
}

\section{Menerapkan kebijakan gender mainstreaming}

Ketika suatu institusi telah mengadopsi konsep gender mainstreaming dengan adanya pembentukan unit khusus, proses selanjutnya ialah membuat kebijakan gender mainstreaming. Dalam pelaksanaannya terdapat prasyarat penting yang diperlukan atau kondisi fasilitasi untuk gender mainstreaming, diantaranya:

\section{1. political will}

Negara harus mendefinisikan kesetaraan gender sebagai salah satu tujuan utamanya. Dengan meratifikasi Konvensi CEDAW menunjukkan komitmen yang nyata. Namun, hanya meratifikasinya tidaklah cukup, gender mainstreaming harus dilakukan sesuai dengan masalah politik. NGO menjadi penting dalam membantu menciptakan kemauan politik ini. Selain itu, pemerintah harus mengeluarkan 'pernyataan misi' yang menyatakan dengan jelas niatnya untuk mengarusutamakan perspektif kesetaraan gender ke dalam semua kebijakan dan program, dan menunjukkan bahwa tujuannya adalah agar program dan kebijakan ini secara efektif akan mempromosikan dan mengarah pada kesetaraan gender.

\section{Specific gender equality policy}

Undang-undang merupakan dasar yang diperlukan untuk mempromosikan kesetaraan gender misalnya Undang-Undang mengenai kesempatan yang sama dan Undang-Undang anti-diskriminasi.

\section{Statistik}

Data tentang situasi perempuan dan laki-laki serta hubungan gender saat ini, mutlak diperlukan untuk gender mainstreaming. Masalahnya bukan hanya statistik tidak selalu dipisahkan berdasarkan jenis kelamin, tetapi juga data tersebut terkadang bias gender.

Specialists on Mainstreaming (EG-S-MS), Strasbourg, May 1998, p.47. 
205 Okta Meryana Dewi | Implementasi Gender Mainstreaming dalam Konteks Pembangunan: Studi Kasus Keberhasilan Kesetaraan Gender di Filipina tahun 2018

\section{Comprehensive knowledge of gender relations}

Gender mainstreaming membutuhkan studi gender yang kuat karena tujuan utamanya ialah untuk mencapai kesetaraan gender. Perbedaan yang ada antar negara, dalam hal tingkat perkembangan studi gender atau tingkat interaksi antara studi gender dan proses kebijakan, menggarisbawahi peran penting yang dimainkan oleh para ahli eksternal ini. Gender mainstreaming melibatkan reorganisasi, pengembangan, implementasi dan evaluasi proses kebijakan,

\section{Necessary funds and human resources}

Sarana keuangan adalah prasyarat mutlak untuk gender mainstreaming. Pengarusutamaan menyiratkan realokasi dana yang ada. Bahkan jika negara menunjukkan kemauan politik yang diperlukan dan memiliki kebijakan kesetaraan gender yang komprehensif dan pengetahuan rinci tentang hubungan gender yang mereka miliki, ini tidak akan memungkinkan mereka untuk mengadaptasi teknik dan alat kebijakan yang ada, membuat saluran baru kerjasama dan menyediakan pelatihan gender untuk pembuat kebijakan.

\section{Participation of women in political and public life and in decision-making processes}

Jelas akan sulit untuk mendapatkan kemauan politik untuk gender mainstreaming jika perempuan tidak sepenuhnya terlibat dalam kehidupan politik dan publik dan dalam pengambilan keputusan secara umum. ${ }^{13}$ Oleh karena itu, penting bagi perempuan untuk memasuki kehidupan politik dan publik dalam jumlah yang jauh lebih besar. Hal tersebut sangat penting bagi perempuan untuk memasuki proses pengambilan keputusan, serta memastikan bahwa berbagai nilai, minat dan

\footnotetext{
${ }^{13}$ UNHCR, GENDER MAINSTREAMING: Conceptual framework, methodology and presentation of good practices, pp.23-25
}

pengalaman hidup perempuan dipertimbangkan saat keputusan dibuat.

\section{Implementasi gender mainstreaming}

Tahap terakhir dari strategi gender mainstreaming adalah implementasi, di mana tantangan terlihat pada sebagian besar praktik secara kelembagaan maupun operasional. ${ }^{14}$ Kegiatan kelembagaan menangani dinamika internal pembangunan organisasi seperti kebijakan, struktur, sistem, dan prosedur. Sedangkan kegiatan operasional membahas kebutuhan untuk mengubah program kerja di mana organisasi terlibat. Secara operasional program pembangunan mendukung dua tujuan yang saling melengkapi dari kesetaraan gender struktural dalam masyarakat, dan pemberdayaan perempuan yang hidup dalam kemiskinan. ${ }^{15}$ Implementasinya masih menghadapi banyak tantangan. Salah satu tantangannya adalah hilangnya potensi tujuan politik feminis dalam proses pengarusutamaan kelembagaan. Oleh karena itu, memastikan tercapainya tujuan kesetaraan gender dalam penerapan gender kebijakan gender mainstreaming membutuhkan upaya dan komitmen yang lebih besar dari semua pemangku kepentingan.

\section{Metodologi}

Dalam penelitian ini, peneliti menggunakan metode penelitian kualitatitf. Penelitian ini bersifat deskriptif dan cenderung mengutamakan analisis dari subjek peneliti. Alasan lainnya karena kualitatif dianggap lebih relevan dalam penelitian implementasi gender mainstreaming di Filipina.

Data yang digunakan dalam penelitian tersebut bersumber dari berbagai literatur seperti

\footnotetext{
${ }^{14}$ Caroline Moser and Annalisa Moser, Gender Mainstreaming Since Beijing: A Review of Success and Limitations in International Institutions, Gender and Development, July, 2005, p.4.

${ }^{15}$ Fenella Forter \& Caroline Sweetmen, 'Mainstraiming Gender in Development A Critical Review', Oxfam GB, United Kingdom, 2005.
} 
buku yang berkaitan dengan pemikiran para ahli terkait gender mainstreaming. Selain itu jurnal, laporan dari pemerintahan, artikel, surat kabar maupun media internet yang kesemuanya berkaitan dengan tema kesetaraan gender, gender mainstreaming, perempuan dan pembangunan, gender di Asia Tenggara dan beberapa kata kunci maupun peneliti terdahulu mengenai gender di Filipina.

\section{Analisis \\ A. Terminologi Gender Mainsraiming dalam Kesetaraan Gender di Filipina}

Negara-negara dikawasan Asia Tenggara memiliki tingkat keragaman yang berbeda dari aspek ekonomi, politik dan budaya, namun dibalik perbedaan itu tingkat pembangunan manusia dapat dikatakan memiliki kesamaan yang baik. Warisan relasi gender yang relatif menguntungkan dan ketahanan serta pragmatisme masyarakat lokal menunjukkan bahwa perempuan Asia Tenggara dapat melihat masa depan yang menjanjikan. Salah satunya Filipina, sejarah kolonialisme oleh Spanyol telah berimplikasi pada ketidaksetaraan gender yang kemudian menanamkan budaya patriarki antara kaum elit dan kaum marginal di kalangan orang Filipina.

Dibalik sejarah tersebut, Filipina memiliki tingkat kesetaraan gender yang lebih baik dibandingkan dengan negara berkembang lainnya dikawasan Asia terkhusus Asia Tenggara. ${ }^{16}$ Global Gender Gap Report 2018, yang mengkaji tingkat kesenjangan antara perempuan dan laki-laki di 149 negara melalui empat dimensi, yaitu Partisipasi dan Peluang Ekonomi, Pencapaian Pendidikan, Kesehatan dan Kelangsungan Hidup, dan Pemberdayaan

\footnotetext{
${ }^{16}$ Manasi Mathkar, 'Philippines leads Asia in gender equality', diakses melalui < https://www.thehindu.com/news/international/philippinesleads-asia-in-gender-equality/article26351544.ece> , diakses pada 9 Agustus 2020.
}

Politik. ${ }^{17}$ Filipina sebagai satu-satunya negara di Asia yang masuk dalam peringkat ke-8 besar global sebagai negara dengan tingkat kesetaraan gender yang tinggi. Kedudukan ini berdampingan dengan negara-negara yang berada di peringkat ke-10 besar seperti Islandia, Norwegia, Swedia, Finlandia, Nikaragua, Rwanda, Selandia Baru, Irlandia, dan Namibia. ${ }^{18}$ Global Gap Gender Report 2018 menunjukkan bahwa Filipina hampir menutup 80 persen dari keseluruhan kesenjangan gendernya. Penilaian kesetaraan gender tertinggi di Filipina pada sektor pendidikan yang dapat dikatakan sepenuhnya menutup kesenjangan gender. ${ }^{19}$ Dilanjutkan dengan dimensi partisipasi dan peluang ekonomi karena adanya peningkatan kesetaraan upah untuk pekerjaan serupa serta mampu menutup kesenjangan gender dalam pemberdayaan politik. Filipina bukanlah negara yang sempurna dalam kesetaraan gender, dalam dimensi kesehatan dan kelangsungan hidup negara ini masih memiliki beberapa catatan untuk memperbaiki diri terutama perbedaan kesehatan perempuan dan laki-laki berdasarkan angka harapan hidup. ${ }^{20}$

Pencapaian Filipina disinyalir karena latar belakang gerakan perempuan yang dinilai sangat aktif dan dinamis. Hal ini menempatkan masalah kesetaraan gender di garis depan wacana nasional dan menghalangi penurunan status perempuan dalam masyarakat modern Filipina. Disisi lain, terdapat banyak organisasi dan LSM yang mendukung kesetaraan gender dan masalah perempuan terkait lainnya. Keuntungan hukum

\footnotetext{
${ }^{17}$ World Economic Forum, 'Global Gender Gap Report 2018', Committed to improving the state of the world, Switzerland, 2018, p.4.

${ }^{19}$ ABS-CBN, 'Philippines is world's 8th best in gender equality, top in Asia: report', diakses melalui < https://news.abs-cbn.com/news/12/19/18/philippines-isworlds-8th-best-in-gender-equality-top-in-asia-report>, pada 1 Agustus 2020.

${ }^{20}$ Sofia Tomacruz, 'Philippines climbs to No. 8 in 2018 Global Gender Gap report', diakses melalui < https://rappler.com/nation/philippines-ranking-globalgender-gap-report-2018>, pada 13 Agustus 2020
} 
207 Okta Meryana Dewi | Implementasi Gender Mainstreaming dalam Konteks Pembangunan: Studi Kasus Keberhasilan Kesetaraan Gender di Filipina tahun 2018

dan kebijakan ini dihasilkan dari suara kuat perempuan yang dimulai bahkan selama perjuangan anti kediktatoran yang memuncak dengan naiknya Corazon Aquino sebagai presiden perempuan pertama di negara itu. ${ }^{21}$

\section{B. Penerapan Kebijakan Gender mainstreaming di Filipina}

Dalam penjelasannya sebelumnya

bahwa dalam penerapan gender mainstreaming terdapat enam prasyarat penting yang diperlukan atau kondisi fasilitasi untuk gender mainstreaming, diantaranya:

1. political will

Pemerintah dan para stakeholder Filipina memasukkan kesetaraan gender dalam kebijakan dan program pembangunan berkelanjutan. Pernyataan ini mengartikan bahwa Filipina dapat menjadi negara yang mempunyai kesetaraan gender tertinggi di Asia, karena pemerintah Filipina sadar akan pentingnya gender dalam pembangunan negara. Seperti adanya sebuah kerangka kerja dari program United Nations Development Programme (UNDP) yang diimplementasikan pemerintah Filipina dalam Undang-undang. Kerangka kerja ini bertujuan untuk memantau serta mengevaluasi program kesetaraan pemberdayaan perempuan. Perwujudaan kebijakan Gender mainstreaming di Filipina, dipengarui dengan beberapa faktor, diantaranya adanya The Magna Carta of Women (MCW), The Philippine Development Plan for Women (PDPW) 1989-1992, dan The Philippine Plan for Gender-Responsive Development (PPGD) 1995-2025.

\section{Specific gender equality policy}

Dalam poin ini menjalaskan terkait peraturann sepesifik yang tertuang dalam Undang-undang yang merupakan dasar yang diperlukan untuk mempromosikan kesetaraan

${ }^{21}$ C. A. Q. Anonuevo, 'An Overview of the Gender Situation in the Philippines,' Friedrich-Ebert-Stiftung Philippine Office, Philippines, September 2000. gender. Dalam mewujudkan hal ini, Filipina memiliki beberapa Undang-Undang dan peraturan diantaranya:

\section{The Magna Carta of Women (Republic Act No. 9710)}

Merupakan sebuah undang-undang yang mendefinisikan bahwa hukum hak asasi perempuan komprehensif yang berupaya menghapus diskriminasi terhadap perempuan dengan mengakui, melindungi, memenuhi dan mempromosikan hak-hak perempuan seperti hak-hak ekonomi, sosial dan politik perempuan. $^{22}$

MCW mengimplementasikan Convention on the Elimination of All Forms of Discrimination Against Women (CEDAW), yang berupaya menghilangkan diskriminasi dengan membongkar struktur sosial, seperti hukum dan institusi, yang memperlakukan perempuan secara tidak setara dan menghalangi mereka untuk mencapai pembangunan sepenuhnya. ${ }^{23}$

Undang-undang tersebut menyatakan bahwa pemerintah Filipina harus "memastikan kesetaraan substantif pria dan wanita" dan memberi mandat kepada Negara untuk mengambil langkah-langkah untuk meninjau, mengubah atau mencabut undang-undang yang diskriminatif terhadap perempuan dalam waktu tiga tahun sejak Undang-undang tersebut berlaku. Untuk memastikan implementasi yang tepat, Presiden Arroyo menugaskan Philippines Commission on Women (PCW) menyusun Implementing Rules and Regulations (IRR) untuk Magna Carta. Tujuan IRR adalah untuk

\footnotetext{
${ }^{22}$ Chairperson MYRNA T. YAO

Nati, Gains in Gender Mainstreaming:

The Philippine Experience, National Commission on the Role of Filipino Women

Republic of the Philippines, Filipina, 2014, p.8.

${ }^{23}$ R. Kiesel \& E. Rottach, The Fade-Away Effect: Findings from a Gender Assessment of Health Policies and Programs in the Philippines, Health Policy Project, Washington DC, 2014, p.10
} 
208 Okta Meryana Dewi | Implementasi Gender Mainstreaming dalam Konteks Pembangunan: Studi Kasus Keberhasilan Kesetaraan Gender di Filipina tahun 2018

menjelaskan setiap ketentuan undang-undang baru melalui departemen pemerintah dan lingkup instansi . Proses penyusunannya telah menjadi upaya nasional dan telah mencakup serangkaian konsultasi regional oleh PCW dengan organisasi masyarakat sipil, unit pemerintah daerah, dan entitas lainnya. ${ }^{24}$

Semua hak dalam Konstitusi Filipina dan hak-hak diakui di bawah instrumen internasional yang ditandatangani dan diratifikasi oleh Filipina, sesuai dengan hukum Filipina akan menjadi hak-hak wanita di bawah Magna Carta of Women. Hak-hak ini akan dinikmati tanpa diskriminasi sejak hukum melarang diskriminasi terhadap perempuan, baik dilakukan oleh badan publik dan swasta atau perseorangan. ${ }^{25}$ Melalui framework ini MCW dapat mendorong kebijakan pemerintah Filipina untuk lebih peduli terhadap perempuan. Pemerintah Filipina percaya dengan diadopsinya $\mathrm{MCW}$ dapat dijadikan sebagai nilai fundamental yang harus tercermin dalam pembangunan dan berpendapat bahwa perempuan adalah agen pembangunan yang aktif, bukan hanya penerima pembangunan yang pasif sehingga memungkinkan partisipasi perempuan dalam perumusan, implementasi dan evaluasi kebijakan dan rencana pembangunan lokal, nasional, dan regional. ${ }^{26}$

Instrumen hukukm lainnya ialah penguatan hukum mengenai kesetaraan gender berangkat dari instrumen internasional yaitu Committee on the Elimination of Discrimination against Women (CEDAW) yang diadopsi pada 1979 oleh Majelis Umum PBB, yaitu sebagai undangundang hak asasi perempuan internasional atau perjanjian internasional pertama dan satusatunya yang membahas secara komprehensif

\footnotetext{
${ }^{24}$ Republic Act 9710: Magna Carta of Women, diakses dari < https://pcw.gov.ph/law/republic-act-9710>, diakses pada 10 Agustus 2020.

${ }^{25}$ Philippine Commission on Women,

${ }^{26}$ PCW, The Magna Carta of Women, Philippine

Commission on Women, Philippines, 2010. p.2.
}

hak-hak perempuan tidak hanya dalam ranah sipil dan politik, tetapi juga dalam ranah ekonomi, kehidupan sosial, budaya dan keluarga. CEDAW menganggap diskriminasi terhadap perempuan sebagai pelanggaran hak asasi manusia. Filipina sebagai negara yang menghormati kedudukan perempuan menjadikan sebagai negara anggota CEDAW. Pada tahun 1980 Filipina menandatangani CEDAW dan meratifikasinya pada $1981 .{ }^{27}$ Berangkat setelah diratifikasinya CEDAW Filipina mengeluarkan kebijakan-kebijakan yang serata gender. Dibuktikan dengan tertulis dalam Konstitusi 1987 pada 2 pasal berikut, yaitu pasal II ayat 14, menegaskan bahwa:

"The State recognizes the role of women in nation-building, and shall ensure the fundamental equality before the law of women and men". Pasal 13 ayat 14 menyatakan bahwa " The State shall protect working women by providing safe and healthful working conditions, taking into account their maternal functions, and such facilities and opportunities that will enhance their welfare and enable them to realize their full potential in the service of the nation. ${ }^{28}$

CEDAW merupakan kunci diterapkannya gender mainstreaming, sehingga adanya ketentuan konstitusional dan upaya perluasan prinsip-prinsipnya, berbagai peraturan perundang-undangan disahkan yang berkaitan dengan berbagai aspek perempuan dan masalah gender, Daftar tersebut meliputi:

\footnotetext{
${ }^{27}$ UNIFEM,'Going CEDAW in the Philippines' The UNIFEM CEDAW South East Asia Programme 20052008, Philippine, 2009.

${ }^{28}$ Philippines's Constitution of 1987 Of The Republic Of The Philippine, 1987, Philippine.
} 
209 Okta Meryana Dewi | Implementasi Gender Mainstreaming dalam Konteks Pembangunan: Studi Kasus Keberhasilan Kesetaraan Gender di Filipina tahun 2018

Tabel.1 Hukum Kebijakan Gender source C.A.Q. Anonuevo (2000)

\begin{tabular}{|c|c|c|}
\hline No & $\begin{array}{l}\text { Kategori } \\
\text { Undang- } \\
\text { Undang }\end{array}$ & $\begin{array}{c}\text { Kebijakan terkait } \\
\text { Gender }\end{array}$ \\
\hline 1 & $\begin{array}{l}\text { Gender and } \\
\text { Development } \\
\text { Law }\end{array}$ & $\begin{array}{l}5 \% \text { dari anggaran } \\
\text { lembaga pemerintah } \\
\text { adalah untuk gender. }\end{array}$ \\
\hline 2 & Party-List Law & $\begin{array}{l}\text { Perempuan sebagai } \\
\text { perwakilan di badan } \\
\text { legislatif melalui } \\
\text { pemilihan partai }\end{array}$ \\
\hline 3 & $\begin{array}{c}\text { Anti-Sexual } \\
\text { Harassment } \\
\text { Law }\end{array}$ & $\begin{array}{l}\text { Mendefinisikan SH dan } \\
\text { menyediakan } \\
\text { mekanisme }\end{array}$ \\
\hline 4 & Anti-Rape Law & $\begin{array}{l}\text { Peningkatan } \\
\text { pemerkosaan sebagai } \\
\text { kejahatan terhadap } \\
\text { seseorang. }\end{array}$ \\
\hline 5 & $\begin{array}{c}\text { Barangay Day } \\
\text { Care Center } \\
\text { Law }\end{array}$ & $\begin{array}{l}\text { Pusat penitipan anak } \\
\text { untuk setiap desa. }\end{array}$ \\
\hline 6 & $\begin{array}{c}\text { Women in } \\
\text { Nation- } \\
\text { Building Law }\end{array}$ & $\begin{array}{l}\text { Anggaran untuk } \\
\text { perempuan dari dana } \\
\text { pembangunan } \\
\text { pemerintah asing dan } \\
\text { lembaga multilateral. }\end{array}$ \\
\hline 7 & $\begin{array}{l}\text { Anti Mail- } \\
\text { Order-Bride } \\
\text { Law }\end{array}$ & $\begin{array}{l}\text { Menjadikan praktik ini } \\
\text { melanggar hukum. }\end{array}$ \\
\hline 8 & $\begin{array}{c}\text { Repatriation } \\
\text { Law }\end{array}$ & $\begin{array}{l}\text { Repatriasi orang } \\
\text { Filipina yang } \\
\text { kehilangan } \\
\text { kewarganegaraan }\end{array}$ \\
\hline 9 & $\begin{array}{c}\text { Non- } \\
\text { Discrimination } \\
\text { Law in Labor } \\
\text { Code }\end{array}$ & $\begin{array}{l}\text { Perlindungan } \\
\text { perempuan dalam } \\
\text { perekrutan dan } \\
\text { pembayaran }\end{array}$ \\
\hline 10 & $\begin{array}{l}\text { Comprehensive } \\
\text { Agrarian } \\
\text { Reform Law }\end{array}$ & $\begin{array}{l}\text { Persamaan hak bagi } \\
\text { perempuan untuk } \\
\text { menjadi penerima tanah }\end{array}$ \\
\hline 11 & $\begin{array}{l}\text { Military } \\
\text { Training } \\
\text { equality }\end{array}$ & $\begin{array}{l}\text { Perempuan dapat } \\
\text { memasuki sekolah } \\
\text { militer dan polisi . }\end{array}$ \\
\hline
\end{tabular}

\section{Statistik}

Data tentang situasi perempuan dan laki-laki serta hubungan gender saat ini, mutlak diperlukan untuk gender mainstreaming.

\section{The Philippine Development Plan for Women (PDPW) 1989-1992}

Fomulasi dasar pemikiran dari PDPW ialah untuk menerjemahkan tujuan Medium-Term Philippine Development Plan (MTPDP) ke dalam kebijakan, program dan tindakan konkrit yang menangani masyarakat miskin dan ketidakberuntungan tidak hanya berdasarkan kelas, kota atau wilayah tetapi juga dalam hal gender yang mengalir dari provosi kesetaraan gender dalam konstitusi: "perempuan, yang merupakan setengah dari populasi bangsa, akan dimobilisasi secara efektif", dan untuk mematuhi konvensi dan perjanjian internasional seperti CEDAW dan langkah-langkah awal untuk kemajuan perempuan (FLS). ${ }^{29}$ Tujuan untuk mempromosikan pembangunan yang responsif gender. PDPW membahas keprihatinan perempuan untuk kesetaraan dan pembangunan di enam bidang utama: individu, keluarga, dan struktur sosial budaya, ekonomi, politik dan hukum yang ada.

\section{The Philippine Plan for Gender- Responsive Development (PPGD) 1995-2025.}

PPGD menjabarkan tujuan dan strategi pembangunan yang menjadikan kesetaraan gender sebagai program dan kebijakan publik. Peraturan yang mengamanatkan rencana kerja selama 30 tahun ini memastikan bahwa kebijakan yang ramah perempuan dapat berakar dan berkembang meskipun ada hambatan yang

\footnotetext{
${ }^{29}$ Philippine Commission on Women, Hightlight of Philippine Development Plan for Women 1989-1992, Printed in the Philippine, March 1989.
} 
210 Okta Meryana Dewi | Implementasi Gender Mainstreaming dalam Konteks Pembangunan: Studi Kasus Keberhasilan Kesetaraan Gender di Filipina tahun 2018

ditimbulkan oleh sikap dan stereotip tradisional. ${ }^{30}$ Kerangka kerja PPGD menuliskan terkait rencana pembiayaan untuk mengimplementasikan Gender and Development (GAD) merupakan pendekatan yang memastikan adanya kesetaraan dalam kontrol, pemanfaatan serta partisipasi yang sama antara perempuan dan laki-laki dalam konteks pembangunan. ${ }^{31}$ Pemerintah Filipina mengalokasikan anggaran dana untuk program GAD sebanyak 5\% dari anggaran pemerintah nasional. Penganggaran dana merupakan suatu mekanisme dalam mewujudkan gender mainstreaming dalam isu gender. $^{32}$ Disisi lain, pengganggaran tersebut sebagai upaya perubahan yang lebih luas menuju pemerintahan responsif gender yang membutuhkan akuntabilitas, transparansi, dan partisipasi.

Tujuan dari anggaran 5\% sebagai dana untuk mendukung pengintegrasian perspektif gender dalam program GAD. ${ }^{33}$ Secara spesifik anggaran GAD digunakan untuk meningkatkan kapasitas perencanaan responsif gender melalui peningkatan kompetensi dan merencanakan serta memelihara data yang dipisahkan menurut jenis kelamin tentang ketenagakerjaan dan pekerjaan. Anggaran GAD juga digunakan untuk mendukung proyek-proyek bantuan langsung kepada perempuan, termasuk keuangan mikro percontohan program untuk membantu pekerja sektor informal (banyak dari mereka adalah perempuan) untuk membuka rekening bank dan untuk memberikan kontribusi melalui ini ke

\footnotetext{
${ }^{30}$ Philippine Commission on Women, Plan Framework of the Philippine Plan for Gender-Responsive Development (PPGD) 1995-2025, National Commission on the Role of Filipino Women, Philippine, 1998, p.7.

31 J. L. Parpart 'et.al,'Theoretical Perspectives on Gender and Development, International Development Research Centre, Canada, 2000, p.39.

${ }^{32}$ J. Frances 'et.al,' Accounting for gender result: A Review of the Philippines GAD of Budget Policy, Women and Gender Institute Miriam Collage, Philippine, 2010, p. 5. ${ }^{33}$ J. Frances 'et.al,' Accounting for gender result: A Review of the Philippines GAD of Budget Policy, Women and Gender Institute Miriam Collage, Philippine, 2010, p. 5.
}

sistem jaminan sosial. Anggaran juga digunakan untuk menyediakan dukungan hukum untuk meningkatkan keselamatan tempat kerja dan akses ke pekerjaan. ${ }^{34}$ Melalaui anggaran GAD inilah Filipina mampu menggerakkan organisasi wanita, menghubungkan masyarakat sipil dan pejabat pemerintah, serta mendukung kegiatankegiatan penting yang berorientasi pada perempuan.

Dari sini dapat dilihat bahwa keseriusan pemerintah Filipina agar program Gender mainstreaming denga menyisihkan sebanyak 5\% dari anggaran dana negara. Apabila dilihat bahwa penerapan gender maisntraiming dana meruoajan kunci utama berjalannya sebuah program, kebijakan maupn peraturan yang berbasis gender. Dari pembuktian ini daoat dilihat bahwa sudah wajar apabila Filipina mampu mencapai kesetaraan gender tertinggi di Asia karena kesadaran politik meskipun belum mencapai klimaks setidaknya menggambarkan bahwa negara ini menghormati gender dalam pembangunan negara. ${ }^{35}$

\section{Comprehensive knowledge of gender relations}

Gender mainstreaming melibatkan reorganisasi, pengembangan, implementasi dan evaluasi proses kebijakan. Di Filipina terdapat The Philippine Commission on Women (PCW) merupakan unit struktur tata kelola pemerintah di bawah Kantor Presiden yang memiliki tanggung jawab sebagai pengawasan untuk memantau komitmen tingkat tinggi kesetaraan gender. PCW bertanggung jawab sebagai katalisator pengarusutamaan gender, otoritas atas keprihatinan perempuan, dan advokat utama

\footnotetext{
${ }^{34}$ Asian Development Bank, 'Good Global Economic and Social Practices to Promote Gender Equality in The Labor Market', Philippine, 2013, p.10.

${ }^{35}$ R. Kiesel \& E.Rottach, 'The Fade-Away Effect Findings from a Gender Assessment of Health Policies and Programs in the Philippines,' U.S. Agency for International Development (USAID), 2014.
} 
pemberdayaan perempuan dan kesetaraan gender di Filipina. ${ }^{36} \mathrm{PCW}$ juga bertindak untuk memasukkan gender ke dalam rencana sektor dan rencana pembangunan seccara keseluruhan di masing-masing lembaga pemerintah. PCW bertanggung jawab atas gender pengarusutamaan di tingkat subnasional pemerintah, memperkuat hubungan dan kemitraan di antara mitra, dan mempromosikan representasi perempuan. PCW telah menerapkan berbagai mekanisme untuk mendukung pengarusutamaan gender dan akuntabilitas. Disisi lain, PCW melakukan studi kebijakan, proyek percontohan, dan menyediakan layanan dan sumber daya teknis perempuan dalam menghadapi kendala yang berbeda dari laki-laki di pasar tenaga kerja.

\section{Necessary funds and human resources}

Sarana keuangan adalah prasyarat mutlak untuk gender mainstreaming. Pengarusutamaan menyiratkan realokasi dana yang ada. Bahkan jika negara menunjukkan kemauan politik yang diperlukan dan memiliki kebijakan kesetaraan gender yang komprehensif dan pengetahuan rinci tentang hubungan gender yang mereka miliki. Dalam hal ini, lembaga pemerintah mengalokasikan setidaknya $5 \%$ dari total anggaran mereka untuk masalah gender dan pembangunan ditambahkan ke Undang-Undang Alokasi Umum tahunan yang dimulai tahun 1995.

\section{Participation of women in political and public life and in decision-making processes}

Pemberdayaan politik perempuan di Filipina dianggap sebagai negara yang mempunyai intesnsitas tertinggi. Filipina dapat dianggap sebagai panutan di bidang ini karena negara ini

\footnotetext{
36 The Philippine Commission on Women, 'History', diupload pada < https://www.pcw.gov.ph/pcw >, diakses pada 12 Agustus 2020.
}

berada di urutan ke-13 dalam peringkat global untuk pemberdayaan politik perempuan. ${ }^{37}$

\section{Implementasi Gender mainstreaming di berbagai Sektor di Filipina}

\section{Sektor Ekonomi}

Program pemberdayaan ekonomi perempuan adalah salah satu prioritas utama Rencana Kerangka Kerja Pemerintah Filipina untuk Perempuan. Penyebabnya karena partisipasi angkatan kerja wanita masih berada pada persentase $50 \%$ lebih rendah daripada pria. Perempuan dicegah memasuki angkatan kerja karena stereotip peran gender, khususnya dalam kaitannya dengan tanggung jawab reproduksi. Akan tetapi partisipasi perempuan dalam perekonomian terus meningkat dibeberapa sektor.

Pertama, pada pekerja professional perempuan dan pekerja teknis (Female Professional and Technical Workers) memiliki persentase tinggi pada tahun 2005 dan 2006 di $61 \%$ dari total pekerja. Kedua, perempuan sebagai menejemen senior (Women as Senior Managers and Household Decision Makers). Menurut laporan 'bussiness in women 2020' dari Grant Thornton International merupakan pengamat yang melihat peluang kepemimpinan bagi wanita di dunia. ${ }^{38}$ Survei yang dilakukan terhadap 4.900 eksekutif senior di 35 negara, menunjukkan bahwa Filipina berada pada peringkat kelima perempuan sebagai posisi manajemen senior di perusahaan Filipina yaitu sebanyak 43\%, dan menduduki peringkat

\footnotetext{
${ }^{37}$ Nadia Setianto, Advancing Gender Equality in Southeast Asia: Case Studies From the Philippines and Singapore, diakses melalui < https://www.internationalaffairs.org.au/australianoutlook/a dvancing-gender-equality-in-southeast-asia-case-studiesfrom-the-philippines-and-singapore/ >, diakses pada 10 september 2021

${ }^{38}$ Punongbayan \& Araullo, 'Women in business: report on the Philippines', Grant Thornton International Business Report 2014, 2014.
} 
212 Okta Meryana Dewi | Implementasi Gender Mainstreaming dalam Konteks Pembangunan: Studi Kasus Keberhasilan Kesetaraan Gender di Filipina tahun 2018

pertama di Asia. ${ }^{39}$ Tiga posisi teratas yang dilaporkan dipegang oleh wanita Filipina adalah kepala keuangan (38 persen), direktur sumber daya manusia (36 persen), dan kepala operasional (23 persen) Laporan tersebut juga menunjukkan bahwa bisnis mengambil lebih banyak tindakan untuk meningkatkan keragaman gender. Sebanyak 94 persen bisnis Filipina secara aktif berupaya menghilangkan hambatan kesetaraan gender, seperti untuk memastikan akses yang setara ke peluang kerja pembangunan ditingkat senior, dan memungkinkan kerja yang fleksibel, meninjau pendekatan rekrutmen, dan memberikan pendampingan dan pembinaan. ${ }^{40}$

\section{Ketiga, Women and Overseas Labor} Migration. Filipina menduduki posisi kedua terbesar didunia sebagai negara pengekpor tenaga kerja. Salah satu proyek pembangunan penting Filipina melibatkan pekerja migran luar negeri, yang tenaga kerjanya dikomoditaskan dalam bentuk pengiriman uang. Hal ini mmeberikan efek positif bagi Filipina karena mampu memainkan peran penting dalam menyumbang PDB negara serta merangsang pertumbuhan ekonomi. Commission on Filipinos Overseas (CFO) memperkirakan bahwa sebanyak 10,4 jut aorang Filipina di luar negeri yang merupakan migran permanen, sementara, atau tidak resmi2, yang berlokasi di lebih dari 200 negara dan wilayah di seluruh dunia. ${ }^{41}$ Berawal pada masa pemerintahan Marcos yang

\footnotetext{
39 Anri Ichimura, 'The Philippines Has the Most Women in Top Business Positions, According to Global Survey', diupload pada 24 Februari 2020 pada laman < https://www.esquiremag.ph/money/industry/women-inbusiness-2020-a00304-20200224>, diakses pada 10 Agutsus 2020.

${ }^{40}$ Bernie, Cahiles-Magkilat, 'PH tops women in business survey', diupload pada 23 Februari 2020, https://mb.com.ph/2020/02/23/ph-tops-women-in-businesssurvey/\#: :text=The\%20Philippines $\% 20$ ranks $\% 20$ first $\% 20$ among,in\%20a\%20senior\%20leadership\%20role>, diaksespada 10 Agustus 2020.

${ }^{41}$ Jean Encinas-Franco, 'Fact Sheet:Filipino Women Migrant Workers', UN Women,
}

tinggi akan inflasi sektor jasa telah menyebabkan peningkatan besar-besaran pekerja yang mencari pekerjaan kontrak di luar negeri. Pekerja migran Filipina diluar negeri didominasi oleh perempuan yaitu sekitar 54,5\% artinya sebanyak 5 persen dari seluruh penduduk Filipina bekerja diluar negeri. ${ }^{42}$ Sebagian besar migran perempuan terlibat dalam pekerjaan rumah tangga dan perawatan. Menurut Central Bank of the Philippines tahun 2016, Overseas Filipinos (OFs) mengirimkan pengiriman uang tunai sebesar USD26,9 miliar merupakan hampir 10 persen dari GNP Filipina. Upaya ini menghubungkan kebijakan migrasi dengan kebijakan pembangunan bahwa adanya perubahan luar biasa dalam pemerintahan di Filipina, Pada tahun 2000-an ekonomi Filipina memasuki periode pertumbuhan yang mengesankan, yaitu antara 2011 dan 2016, PDB tumbuh rata-rata sekitar 6 persen per tahun. ${ }^{43}$

\section{Sektor Pendidikan}

Pada dasarnya Filipina ialah negara yang memberikan perhatian besar pada bidang pendidikan. Pernyataan tersebut tertulis dalam The Constitution of the Republic of the Philippines 1987 bahwa Filipina menetapkan prioritas anggaran tertinggi untuk pendidikan. ${ }^{44}$ Pasca perang dunia ke-2, 1948 sampai 1970 pendidikan Filipina lebih didominasi oleh para laki-laki dibandingkan perempuan. Kondisi berbalik setelah tahun 70-an, kedudukan

\footnotetext{
42 Sabiha Iman Mohyuddin, Female Migrant Labor in the Philippines: The Institutionalization of Traditional Gender Roles in the Name of Economic Development, Pursuit', The Journal of Undergraduate Research at the University of Tennessee, January 2017, 8(1), p.97

${ }^{43}$ Maruja M.B. Asis, 'The Philippines: Beyond Labor Migration, Toward Development and (Possibly) Return, diupload pada 12 Juli 2017, pada laman < https://www.migrationpolicy.org/article/philippinesbeyond-labor-migration-toward-development-and-possiblyreturn >,diakses pada 10 Agustus 2020.

${ }^{44}$ World Bank, Gender Equality and Development: World Development Report 2012, p. 16.
} 
213 Okta Meryana Dewi | Implementasi Gender Mainstreaming dalam Konteks Pembangunan: Studi Kasus Keberhasilan Kesetaraan Gender di Filipina tahun 2018

perempuan dalam sektor pendidikan mengungguli laki-laki di Filipina.

Dalam program GAD pendidikan di Filipina cenderung menjadi kebalikan dari apa yang ditemukan di banyak negara lain. Angka partisipasi untuk anak perempuan dan semua indikator pendidikan lainnya melebihi anak lakilaki. ${ }^{45}$ Berkaitan dengan hasil prestasi belajar, data juga mengungkapkan bahwa angka melek huruf fungsional pada anak usia 10-15 tahun pada anak laki-laki lebih rendah $(55,5 \%)$ dibandingkan pada anak perempuan $(63,0 \%)^{46}$. Meski begitu, melek huruf adalah universal di Filipina dengan tingkat melek huruf di atas $98 \%$ untuk kedua jenis kelamin.

Grafik 2. Angka Penyelesaian Pendidikan (Laki-laki \& Perempuan) tahun 1948-2015

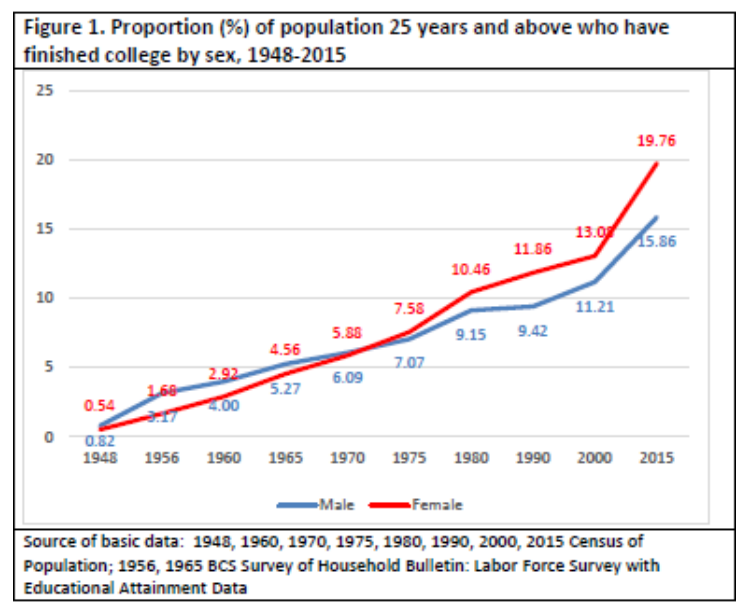

Source: Vicente B. Paqueo \& Aniceto C. Orbeta (2019)

Studi menunjukkan bahwa anak lakilaki melakukannya untuk bekerja lebih banyak untuk menambah pendapatan keluarga. Menurut penelitian yang sama, anak laki-laki melaporkan kurangnya minat di sekolah, yang mungkin juga

\footnotetext{
${ }^{45}$ M. Hega, 'Participation of Women in Philippine Politics and Society: A Situationer,' Friedrich-Ebert-Stiftung Philippine Office, Philippine, 2003.

${ }^{46}$ Vicente B. Paqueo and Aniceto C. Orbeta Jr, 'Gender Equity in Education: Helping the Boys Catch Up', Philippine Institute for Development Studies, April 2019, p.2.
}

menyebabkan rendahnya tingkat pendaftaran mereka.

\section{Sektor Kesehatan}

Bagian 17 dari MCW mengamanatkan pemerintah untuk mengamankan hak perempuan atas kesehatan melalui penyediaan layanan kesehatan yang komprehensif. ${ }^{47}$ Pemerintah menyediakan sarana dan prasarana sehingga upaya penanganan kesehatan antara perempuan dan laki-laki setara. Dalam sektor kesehatan perempuan biasanya lebih cenderung tinggi mengalami tingkat kematian Ibu atau maternal mortality ratio (MMR). ${ }^{48}$ Sebuah survei memaparkan bawa Filipina telah membuat kemajuan substansial dalam meningkatkan kesehatan dan kesejahteraan warganya. Angka kematian anak menurun dari 80 kematian per 1.000 kelahiran hidup pada tahun 1990 menjadi 34 kematian per 1.000 pada tahun $2008 .{ }^{49}$

Program asuransi kesehatan nasional pada tahun 1994 yang merupakan salah satu dari tuga dorongan utama untuk mencapai cakupan kesehatan universal dibawah agenda kesehatan Aquino, yaitu The Philippine Health Insurance Corporation (PhilHealth). Program ini mengambil dimensi yang lebih responsif gender. Rencana Women's EDGE mencatat:

Gender-responsive measures for social protection were initiated by PhilHealth through the issuance of Board Resolution No. 1479, S 2011, approving the implementation of the partial subsidy scheme for woman microentrepreneurs, small self-employed and underground economy workers, and PhilHealth Board Resolution 1613, stipulating the

\footnotetext{
${ }^{47} \mathrm{PCW}$, Magna Carta of Women Implementing Rule and Regulations, Philippine Commission on Women, 2010. ${ }^{48}$ M. M. Dayrit 'et.al,' 'The Philippines Health System Review, World Health Organization,' Asia Pacific Observatory on Health Systems and Policies, 8, (2), 2018, p.35.

${ }^{49}$ R. Kiesel \& E. Rottach, The Fade-Away Effect: Findings from a Gender Assessment of Health Policies and Programs in the Philippines, Health Policy Project,p.4
} 
214 Okta Meryana Dewi | Implementasi Gender Mainstreaming dalam Konteks Pembangunan: Studi Kasus Keberhasilan Kesetaraan Gender di Filipina tahun 2018

prioritization of unmarried mothers and pregnant women in guaranteeing access to health insurance. ${ }^{50}$

Misalnya, ketentuan khusus diberlakukan untuk memberikan perawatan medis gratis kepada orang miskin melalui distribusi kartu PhilHealth oleh walikota setempat dan kapten barangay (desa). Awalnya, kartu-kartu ini hanya dibagikan kepada laki-laki yang dianggap sebagai kepala keluarga. Modifikasi terbaru, bagaimanapun, telah memungkinkan distribusi kartu (atau kartu duplikat) kepada perempuan.

\section{Sektor Partisipasi Politik}

Di Asia Tenggara, tingkat partisipasi perempuan di parlemen tertinggi diduduki oleh Filipina yang mencapai di atas rata-rata yaitu sekitar 23\%. Representasi politik perempuan di Filipina memiliki bagian yang sama besar walaupun cendurung perempuan masih berada pada titik rendah dibandingkan laki-laki. Pernyaan tersebut dikaitkan dengan fakta bahwa baik laki-laki maupun perempuan diambil dari latar belakang sosial ekonomi. Beberapa pengamat menyatakan bahwa beberapa perempuan politisi menjabat sebagai "placeholder" ketika anggota laki-laki dari dinasti politik harus meninggalkan kedudukannya karena batasan masa kerja. ${ }^{51}$ Tidak bisa dipungkiri bahwa faktor kelas dan ikata keluarga memaikan peran kunci dalam jalur representasi perempuan dikancah politik. ${ }^{52}$ Salah satu pencapaian terbesar Filipina dalam kesetaraan gender dibidang partisipasi politk ialah mampu menghasilkan dua Presiden perempuan, yaitu Maria Corazon Sumulong Cojuangco Aquino (Cory Aquino) dan Maria

\footnotetext{
${ }^{50}$ Ibid,p. 10

${ }^{51}$ United States Department of State, 'Country Reports on Human Rights Practices for 2018, United States', 2018, p.24.

${ }^{52}$ Nankyung Choi, Women's political pathways in Southeast Asia, International Feminist Journal of Politics, 21(2), 224-248, DOI: 10.1080/14616742.2018.1523683
}

Gloria Macaraeg Macapagal Arroyo serta perempuan menduduki 27 persen kursi kongres (Persatuan Antar Parlemen dan Perempuan PBB). Disisi lain, peningkatan mencolok dalam jumlah perempuan terpilih yaitu di DPR dan jumlah walikota perempuan juga secara konsisten terus meningkat sejak 1995. ${ }^{53}$

Dari penjelasan ketiga argumen bahwa keberhasilan Filipina dalam penerapan Gender mainstreaming disebabkan karena adanya 3 faktor utama yaitu adanya penerapan UndangUndang Magna Carta Women (MCW), adanya rencana kerja nasional atau The Philippine Plan for Gender-Responsive Development (PPGD) 1995-2025, dan pengimplementasiannya Gender mainstreaming secara langsung diberbagai sektor yang menggambarkan keseimbangan antara perempuan dan laki-laki. Yang kemudian diartikan bahwa upaya yang telah dilakukan pemerintah Filipina dalam mengimplementasikan GAD dianggap sebagai suatu keberhasilan dalam program pembangunan di Filipina.

Apabila dikaitkan dengan konteks pembangunan, menurut Amartya Sen bahwa "development as a freedom" pembangunan identik dengan kebebasan, artinya bebas menyampaikan ekspresi, bebas untuk menentukan apa yang terbaik untuk kehidupannya. ${ }^{54}$ Kebebasan disini berkaitan erat dengan Hak Asasi Manusia, dimana mereka mempunyai hak mutlak yang tidak bisa diganggu oleh siapapun termasuk juga oleh negara. Sama halnya dalam salah satu sektor implementasi GAD di Filipina yaitu partisipasi politik. Pemerintah Filipina dinilai sangat responsif dan bertindak adil karena mampu menerapkan kebijakan bahkan dicantumkan dalam undang-undang untuk memberikan

\footnotetext{
${ }^{53}$ World Bank, Gender Equality and Development: World Development Report 2012, p. 44.

54 A. Sen, Developement As Freedom, Oxford University Press, New York, 1999, p.4.
} 
kesempatan kepada perempuan untuk terlibat, berpartisipasi dan menyuarakan haknya dalam panggung perpolitikan.

Dari ketiga opini dan argumen diatas menunjukkan suatu pembuktian keberhasilan implementasi GAD di Filipina. Sehingga, Filipina layak dinobatkan sebagai negara tertinggi dan role model tingkat kesetaraan gender di Asia. Pemerintah Filipina sangat peduli dan memperhatikan kemanfaatan pembangunan untuk semua kalangan. Sehingga kepentingan-kepentingan yang terwujud tidak hanya dari para kaum elit laki-laki. GAD mengedepankan persoalan ini yaitu kebebasan, karena apabila tidak adanya kebebasan berekspresi baik dari sektor ekonomi, pendidikan, kesehatan bahkan politik maka pembangunan hanya dirasakan oleh kelompokkelompok tertentu saja.

\section{Kesimpulan}

Berdasarkan penjabaran diatas, maka diapat disimpulkan bahwa kesadaran dan keseriusan pemerintah Filipina dalam implementasi gender mainstreaming menjadi suatu penyebab keberhasilan kesetaraan gender di Filipina. Di sisi lain, penerapan keenam prasyarat dalam gender meainstraiming dianggap mememnuhi, sehingga menjadikan gender mainstreaming berjalan sepenuhnya di Filipina. Hal tersebut dibuktikan dengan adanya adopsi terminologi gender maisntraiming pada semua program mauoun peraturan yang lebih menekankan perempuan dalam prospek pembangunan. Pembuktian selanjutnya penerapan gender mainstreaming di Filipina yaitu adanya undang-undang Magna Carta women (MCW) yang merupakan kerangka atau upaya legislasi, pelaksanaan, dukungan, dan program upaya kesetaraan gender dari pemerintah, masyarakat sipil, dan pemangku kepentingan lainnya. Adanya The Philippine Development Plan for Women (PDPW) 19891992 bertujuan untuk mempromosikan pembangunan yang responsif gender. Dan adanya The Philippine Plan for GenderResponsive Development (PPGD) 1995-2025 sebagai program pembangunan gender yang menerapkan alokasi anggaran dana untuk program GAD sebanyak 5\% dari anggaran pemerintah nasional. Beberapa program dan peraturan yang diterapan oleh pemerintah Filipina tersebut merupakan program atau peraturan inti dalam mewujudkan kesetaraan gender. Dan kesemua program tersebut diawasi oleh The Philippine Commission on Women $(P C W)$ yang bertanggungjawab untuk memantau komitmen penerapan gender mainstreaming. Setelah undang-undangg, peraturan maupun program yang dirancang oleh Filipina, kemudian diimplementasikan diberbagai sektor sebagai penilaian kesetaraan gender yaitu partisipasi ekonomi dan peluang, pencapaian pendidikan, kesehatan dan kelangsungan hidup, dan pemberdayaan politik. Dengan ini dapat dikatakan bahwa tidak mengherankan apabila Filipna mampu menduduki peringkat pertama kesetaraan gender di Asia. Apabila dianalisis dari segi hukum yang meliputi undang-undang serta program yang ada Filipina dapat dikatakan lebih baik daripada negara tetangganya, meskipun belum bisa dikatakan sempurna dalam implementasinya. 
216 Okta Meryana Dewi | Implementasi Gender Mainstreaming dalam Konteks Pembangunan: Studi Kasus Keberhasilan Kesetaraan Gender di Filipina tahun 2018

\section{Daftar Pustaka}

Alami, A. N. (2008). The Implementation of Gender Mainstreaming in ASEAN. The Indonesian Journal of Southeast Asian Studies, 1(2), pp. 185-207.

ABS-CBN. (2019, December 19). Retrieved August 1, 2020, from Philippines is world's 8th best in gender equality, top in Asia: report: https://news.abscbn.com/news/12/19/18/philippines-isworlds-8th-best-in-gender-equality-topin-asia-report

Anonuevo, C. A. (2000). An Overview of the Gender Situation in the Philippines.

Araullo, P. \&. ( 2014). Women in business: report on the Philippines. Philippine: Grant Thornton International Business Report 2014.

Asian Development Bank. (2013). Good Global Economic and Social Practices to Promote Gender Equality in The Labor Market. Philippine: Asian Development Bank.

Asis, M. M. (2017, July 12). The Philippines: Beyond Labor Migration, Toward Development and (Possibly) Return. Retrieved 14 August , 2020, from https://www.migrationpolicy.org/article/ philippines-beyond-labor-migrationtoward-development-and-possiblyreturn

Cahiles-Magkilat, B. (2020, February 23). PH tops women in business survey. Retrieved August 10, 2020, from https://mb.com.ph/2020/02/23/ph-topswomen-in-business-survey/\#: :text=The Philippines ranks first among,in a senior leadership role
Choi, N. (2018). Women's political pathways in Southeast Asia. International Feminist Journal of Politics, 21(2), 224-248, DOI: 10.1080/14616742.2018.1523683.

(eds), J. L. (2000). Theoretical Perspectives on Gender and Development. Canada: International Development Research Centre.

'et.al', M. M. (2018). The Philippines Health System Review, World Health Organization. Asia Pacific Observatory on Health Systems and Policies, 8(2).

Hega, M. (2003). Participation of Women in Philippine Politics and Society: A Situationer. Philippine: Friedrich-EbertStiftung Philippine Office.

Ichimura, A. (2020, 24 February ). he Philippines Has the Most Women in Top Business Positions, According to Global Survey. Retrieved August 10, 2020, from https://www.esquiremag.ph/money/indu stry/women-in-business-2020-a0030420200224

Jr, V. B. (2019). Gender Equity in Education: Helping the Boys Catch Up. Philippine: Philippine Institute for Development Studies.

Kabonesa, C. (2005). Gender Mainstreaming and Implications for Peace. In D. \&. E.N.Togboa, Gender and Peace Building in Africa (p. 17). Costa Rica: University for Peace.

Mathkar, M. (2019, February 23). Retrieved August 9, 2020, from Philippines leads Asia in gender equality: https://www.thehindu.com/news/internat ional/philippines-leads-asia-in-genderequality/article26351544.ece 
217 Okta Meryana Dewi | Implementasi Gender Mainstreaming dalam Konteks Pembangunan: Studi Kasus Keberhasilan Kesetaraan Gender di Filipina tahun 2018

Mohyuddin, S. I. (2017). Female Migrant Labor in the Philippines: The Institutionalization of Traditional Gender Roles in the Name of Economic Development. he Journal of Undergraduate Research at the University of Tennessee, 8(1).

Moser, C. M. (2005). Gender Mainstreaming Since Beijing: A Review of Success and Limitations in International Institutions. New York : Gender and Development.

PCW. (1987). Philippines's Constitution of 1987 Of The Republic Of The Philippine. Philippine.

PCW. (1989). Philippine Commission on Women. Philippine: Hightlight of Philippine Development Plan for Women 1989-1992.

PCW. (1998). Plan Framework of the Philippine Plan for Gender-Responsive Development (PPGD) 1995-2025.

Philippine: National Commission on the Role of Filipino Women.

PCW. (2009). Retrieved August 10, 2020, from Republic Act 9710: Magna Carta of Women: https://pcw.gov.ph/law/republic-act9710

PCW. (2009). History. Retrieved August 12, 2020, from https://www.pcw.gov.ph/pcw

PCW. (2010). Magna Carta of Women Implementing Rule and Regulations. Philippine: Philippine Commission on Women.

PCW. (2010). The Magna Carta of Women. 2010: Philippine Commission on Women.
Philippines: Friedrich-Ebert-Stiftung Philippine Office.

Rottach, R. K. (2014). The Fade-Away Effect: Findings from a Gender Assessment of Health Policies and Programs in the Philippines. Washington DC: Health Policy Project.

Ryan, B. (2007). ender Mainstreaming and Empowerment Concepts studied in a development cooperation programme in Kenya supported by Sweden,. Master Thesis in Africa and International Development.

Sen, A., Developement As Freedom, Oxford University Press, New York, 1999.

Sjoberg, L. (2010). Gender and International Security Feminist perspectives. New York: Routledge.

Sweetmen, F. F. (2005). Mainstraiming Gender in Development A Critical Review. United Kingdom: Oxfam GB.

Tomacruz, S. (2018, December 18). Retrieved August 13, 2020, from Philippines climbs to No. 8 in 2018 Global Gender Gap report: https://rappler.com/nation/philippinesranking-global-gender-gap-report-2018

UNHCR. (1998). Gender mainstreaming: Conceptual framework, methodology and presentation of goodFinal Report of Activities of the Group of Specialists on Mainstreaming (EG-S-MS), . Strasbourg: Final Report of Activities of the Group of Specialists on Mainstreaming (EG-S-MS).

UNIFEM. (2009). Going CEDAW in the Philippines. Philippine: The UNIFEM CEDAW South East Asia Programme 2005-2008. 
United Nations. (2002). Gender mainstreaming an Overview. New York: Office of the Special Adviser on Gender Issues and Advancement of Women,.

United States Department of State. (2018). Country Reports on Human Rights Practices for 2018. United States.

United Women. (1995). Beijing Declaration and Platform Action : Beijing +5 Political Declaration and Outcome. New York: United Women.

World Economic Forum. (2018). Global Gender Gap Report 2018. Switzerland: World Economic Forum.
World Bank. (2011). Gender Equality and Development: World Development Report 2012. Washington DC: The International Bank for Reconstruction and Development.

World Bank. (2012). Gender Equality and Development: World Development Report 2012. Washington DC: World Bank .

World Bank. (2014). Gender Equality and Development: World Development Report 2012. Washington DC: World Bank . 